\title{
PENGEMBANGAN INSTRUMEN EVALUASI TWO-TIER MULTIPLE CHOICE TERHADAP LITERASI SAINS BERBANTUAN PERSONAL COMPUTER
}

\author{
Nukhbatul Bidayati Haka ${ }^{1^{*}}$, Abdul Hamid ${ }^{2}$, Nurhidayah ${ }^{3}$, Aryani Dwi \\ Kesumawardhani ${ }^{4}$, Mahmud Rudhini ${ }^{5}$, Ranti Anda Riski ${ }^{6}$ \\ 1, 2, 3, 4, 5, 6 Pendidikan Biologi Fakultas Tarbiyah dan Keguruan UIN Raden Intan Lampung, Indonesia \\ *Email: nukhbatulbidayatihaka@radenintan.ac.id
}

Received: Oktober $2^{\text {nd }}, 2019$. Accepted: November $2^{\text {nd }}, 2019$. Published: December $29^{\text {th }}, 2019$

\begin{abstract}
This research aims to develop a two-tier multiple choice assessment instrument to measure learners' science literacy using personal computer in decent and interesting environmental change material. This research is a Research and Development $(R \& D)$ study using the Borg and Gall procedure up to 7 steps. The data used in this study are media experts, evaluation experts, linguists, educator responses, student responses and the results of scientific literacy. Based on the research that the instrument evaluations two-tier multiple choice to measure learners' science literacy $X$ using personal computer on material change environment, it can be concluded that the development of TWO-tier evaluation instruments Multiple choice of a personal computer-assisted science literacy with development methods according to Borg and Gall to the seventh step including Research and information collecting, planning, Develop prelimiery form of product, Prelimiery field testing, Main product revision, Main field testing and Operational product revision. After conducting test of evaluation instrument TWO-tier multiple choice to measure science literacy using personal computer in biology subjects has obtained assessment with very decent and very interesting criteria.
\end{abstract}

Keyword: Instrument Evauation; Scientific Literacy; Personal Computer; Two-tier Multiple Choice

\begin{abstract}
Abstrak
Penelitian ini bertujuan untuk mengembangkan instrument evaluasi two-tier multiple choice untuk mengukur literasi sains peserta didik menggunakan personal computer pada materi perubahan lingkungan yang layak dan menarik. Jenis penelitian ini yakni penelitian Research and Development (R\&D) yang menggunakan prosedur Borg and Gall sampai dengan 7 langkah. Dalam penelitian ini memakai data ahli media, ahli evaluasi, ahli bahasa, respon pendidik, respon peserta didik dan hasil literasi sains. Berdasarkan hasil penelitian bahwa instrument evaluasi two-tier multiple choice untuk mengukur literasi sains peserta didik X menggunakan personal computer pada materi perubahan lingkungan, dapat disimpulkan bahwa pengembangan instrumen evaluasi Two-tier multiple choice terhadap literasi sains berbantuan personal computer dengan metode pengembangan menurut Borg and Gall sampai langkah ketujuh diantaranya yakni Research and information collecting, planning, Develop prelimiery form of product, Prelimiery field testing, Main product revision, Main field testing dan Operational product revision. Setelah melakukan uji terhadap instrument evaluasi Two-tier multiple choice untuk mengukur literasi sains menggunakan personal computer pada mata pelajaran biologi telah diperoleh penilaian dengan kriteria sangat layak dan sangat menarik.

Kata Kunci : Instrumen Evaluasi; Literasi Sains; Personal Computer; Two-tier Multiple Choice
\end{abstract}




\section{PENDAHULUAN}

Standar penilaian pendidikan berhubungan dengan prosedur, mekanisme, serta instrumen dari penilaian hasil belajar peserta didik (Anwar \& Fakhruddin, 2016; Salamah, 2018; Yulianti, 2014). Keberhasilan pada proses pembelajaran yang dinilai dari pendidik dilakukan dengan cara berkelanjutan hingga dapat mengamati berlangsungnya keberhasilan pembelajaran (Sulfemi, 2018; THAHIR dkk., 2019), perkembangan dan pembaruan dari keberhasilan pembelajaran tersebut dengan cara seperti ulangan harian, ulangan ditengah semester, ulangan diakhir semester serta ulangan kenaikan kelas (FITRIAWATI, 2018; Jannah, 2013).

Proses evaluasi saat pembelajaran banyak ditemukan permasalahan (Aminoto, 2014; Amir, 2015). Pembelajaran sains di bidang pendidikan memiliki tujuan menumbuh kembangkan keahlian berfikir logis, deduksi memakai draf serta dasar sains (Puspitasari \& Rodiyana, 2019). Di Indonesia juga dapat dikatakan memiliki kemampuan dengan mengenali ingatan rasional berlandaskan bukti yang sederhana misalnya pada nama, bukti, kata peristilahan serta ringkasan yang lugas (Haryati, 2014). Saat proses pembelajaran peserta didik diarahkan untuk dapat memahami materi pelajaran dengan baik (Karyanti \& Komarudin, 2017; Muhson, 2010), namun terkadang peserta didik tidak selalu menyerap informasi tersebut sepenuhnya (Indriani \& Suranto, 2016), sehingga apa yang mereka pahami mengenai konsep ilmiah sering kali berbeda dengan konsep para ahli (Lesmono dkk., 2017). Ketidaksesuaian pemahaman konsep tersebut dapat dikatakan dengan salah konsep (Adiansyah Syahrul, 2015; Dzulfikar \& Vitantri, 2017).

Two-tier Multiple Choice (TTMC) berupa soal pilihan ganda dengan dua tingkat pertama kali dikembangkan oleh David F. Treagus (Dawati dkk., 2017). Pada tingkat pertama soal perihal rancangan yang akan diuji cobakan sedangkan tingkat kedua tentang alasan setiap jawaban yang ada pada pertanyaan. Namun, pendidik juga bisa memengaruhi konsepsi peserta didik selain itu juga tes pilihan ganda dua tingkat ini mudah dilaksanakan dan mudah juga bagi pendidik untuk memberikan penilaian (Septiani \& Sumarni, 2014). Two-tier multiple choice ini sangat efektif untuk menentukan miskonsepsi peserta didik dan dapat dipakai sebagai alternatif penilaian tes evaluasi terhadap prestasi belajar peserta didik (Ardiansyah \& Bahriah, 2016). Adapun Kelebihan dan kekurangan Two-tier Multiple Choice antara lain (Maunah, 2014); Keunggulannya yakni penilaian soalnya lebih faktual, 
cepat serta mudah sedangkan Kelemahannya tidak bisa digunakan untuk mengetahui kemampuan peserta didik misalnya pada soal berbentuk essay.

Pendidik sering menggunakan tes formatif disekolah dalam bentuk tes tertulis pilihan ganda. Soal tersebut juga kurang jika untuk mengetahui kemampuan psikologis yang tinggi. Salah satu cara yang dapat digunakan untuk mengetahui kemampuan berfikir tinggi berdasarkan psikolologis (Agustiana dkk., 2019; Komarudin dkk., 2014; Nofiana \& Karyanto, 2013). Seperti penelitian sebelumnya yang meneliti Two-Tier Multiple Choice (Damayanti dkk., 2018; Dewantari, 2015; Hikmah dkk., 2017; Ratnasari dkk., 2017) namun yang membedakan dengan penelitian sebelumnya ialah belum diteliti terhadap kemampuan literasi dengan personal computer. Berdasarkan latar belakang masalah diatas, maka tujuan penelitian ini ialah untuk mengukur literasi sains peserta didik menggunakan personal computer supaya tercapai evaluasi pembelajaran sesuai dengan tujuan kompetensi dasar.

\section{METODE}

Metode yang digunakan pada penelitian ini menggunakan metode dari Borg and Gall yang langkah-langkahnya sudah disederhakan menjadi tujuh langkah sesuai dengan konsep (Sanjaya, 2013). Ke tujuh langkah yang digunakan yakni Research and information collecting (studi pendahuluan), planning (rencana penelitian), Develop prelimiery form of product (pengembangan desain), Prelimiery field testing (uji coba lapangan terbatas), Main product revision (revisi hasil dari uji lapangan secara terbatas), Main field testing (uji coba produk secara lebih luas) dan Operational product revision (revisi hasil uji coba produk secara lebih luas).

Populasi pada penelitian ini yakni seluruh kelas X SMA Al-Azhar 3 Bandar Lampung dan SMA Muhamadiyah 2 Bandar Lampung dengan diambil beberapa sampel menggunakan teknik purposive sampling yaitu dengan cara memilih sekolah yang memiliki fasilitas computer sebagai fasilitas yang menujang penggunaan instrumen evaluasi yang dikembangkan. Adapun sampel yang diambil pada uji coba sejumlah 10 orang, sedangkan pada uji coba luasnya senbanyak 30 orang (Komarudin \& Permana, 2019; Rodiawati \& Komarudin, 2018).

Instrumen penelitian yang digunakan terdapat 6 intsrumen diantanranya yang pertama adalah angket validasi ahli media diperlukan untuk mendapatkan penilaian dan masukan tentang desain aplikasi dan kelayakan aplikasi yang dikembangkan, instrumen yang ke dua 
yaitu angket validasi ahli evaluasi diperlukan untuk mendapatkan penilaian dan masukan berkenaan dengan kelayakan media berdasarkan konsep evaluasi, yang ke tiga yaitu engket validasi ahli bahasa diperlukan untuk memperoleh penilaian dari ahli bahasa mengenai tata bahasa yang sinkron terhadap kaidah PUEBI (Pedoman Umum Ejaan Bahasa Indonesia), selanjutnya instrumen yang ke empat yaitu angket tanggapan pendidik diperlukan untuk Mendapatkan saran dan penilaian berkenaan dengan media yang akan dibuat, instrumen yang ke lima yaitu angket tanggapan pendidik diperlukan untuk Mendapatkan masukkan dalam penggunaan media.

Tingkat pengukuran dalam penelitian ini menggunakan interval. Data interval dianalisis dengan cara menghitung presentasi jawaban angket dalam setiap item dengan membandingkan jumlah jawaban dengan nilai ideal angket dengan dikalikan persentase untuh (100\%). Sedangkan nilai skor rata-rata persentase angket dengan membandingkan jumlah persentase dengan jumlah item pada angket yang digunakan.

\section{HASIL DAN PEMBAHASAN}

Produk yang dihasilkan berupa aplikasi instrumen evaluasi Two-tier multiple choice menggunakan personal computer yang dibuat menggunakan software construct 2 sebagai evaluasi pembelajaran yang mengikuti perkembangan teknologi yang diharapkan mampu mengukur ketercapaian literasi sains peserta didik. Pengembangan media instrumen evaluasi Two-tier multiple choice ini menggunakan langkah penelitian dan pengembangan (Research and Development) yang dikemukakan oleh Borg and Gall. Pengujian aplikasi instrumen evaluasi Two-tier multiple choice dilaksanakan pada peserta didik kelas X SMA Al-Azhar 3 Bandar Lampung dan . peserta didik kelas X SMA Muhamadiyah 2 Bandar Lampung Hasil yang diperoleh melalui studi lapangan yang dilaksankan di 2 sekolah tersebut bahwasannya : (a) Evaluasi pada pelajaran biologi pada kelas $\mathrm{X}$ di SMA Muhamadiyah 2 Bandar Lampung dan di SMA Al-Azhar 3 Bandar Lampung hanya menggunakan evaluasi yang bersifat paper and pencil test. (b) Kurangnya pendidik dalam mengidentifikasi miskonsepsi peserta didik. (c) Belum terdapat istrumen evaluasi yang digunakan untuk mengukur literasi sains peserta didik. (d) Belum terdapat instrumen evaluasi Two-tier multiple choice untuk mengukur literasi sains peserta didik dengan menggunakan personal computer. Sehingga peserta didik tertarik jika pada evaluasi 
pembelajaran materi perubahan lingkungan digunakan dalam bentuk aplikasi instrumen evaluasi Two-tier multiple choice menggunakan personal computer.

Berdasarkan data studi lapangan yang telah dilakukan di SMA Al-Azhar 3 Bandar Lampung dan SMA Muhamadiyah 2 Bandar Lampung mendapat kesimpulan bahwa seiring perkembangan kurikulum pembelajaran yang berbasis teknologi dan informasi pemanfaatan instrumen evaluasi pembelajaran Two-tier multiple choice menggunakan personl computer sangat dibutuhkan dalam pembelajaran biologi saat ini. Pengembangan aplikasi pada proses pembelajaran sangat dibutuhkan dalam pemanfaatkan adanya alat teknologi misalnya computer sehingga dapat dipergunakan lebih positif dan bermanfaat bagi peserta didik. Sehingga perkembangan teknologi informasi dapat menghasilkan konstribusi ke arah perkembangan pendidikan yang berkualitas.

Berbagai menu yang disajikan dalam instrumen evaluasi Two-tier multiple choice menggunakan personal computer diantaranya yakni menu kurikulum, pengantar two-tier multiple choice, petunjuk penggunaan, tes two-tier multiple choice, dan biografi pengembang aplikasi. Untuk lebih jelasnya mengenai desain aplikasi instrumen evaluasi Two-tier multiple choice menggunakan personal computer, berikut disajikan gambaran dari desain aplikasi.

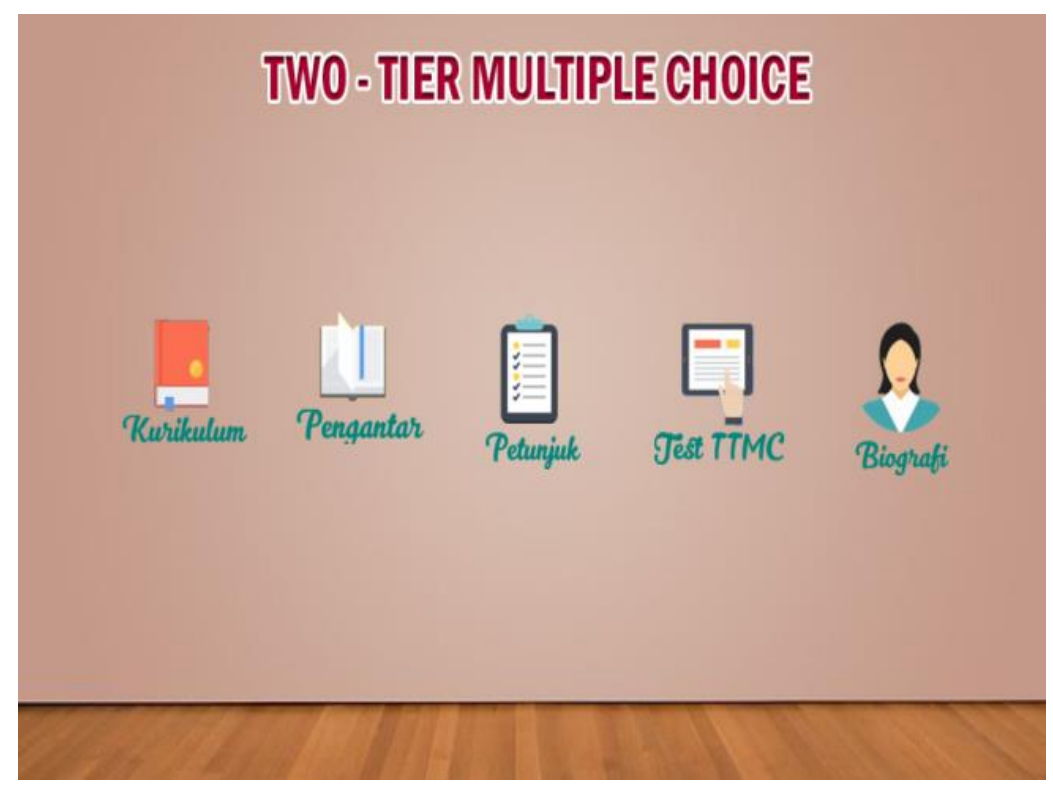

Gambar 1. Tampilan Menu two-tier multiple choice 


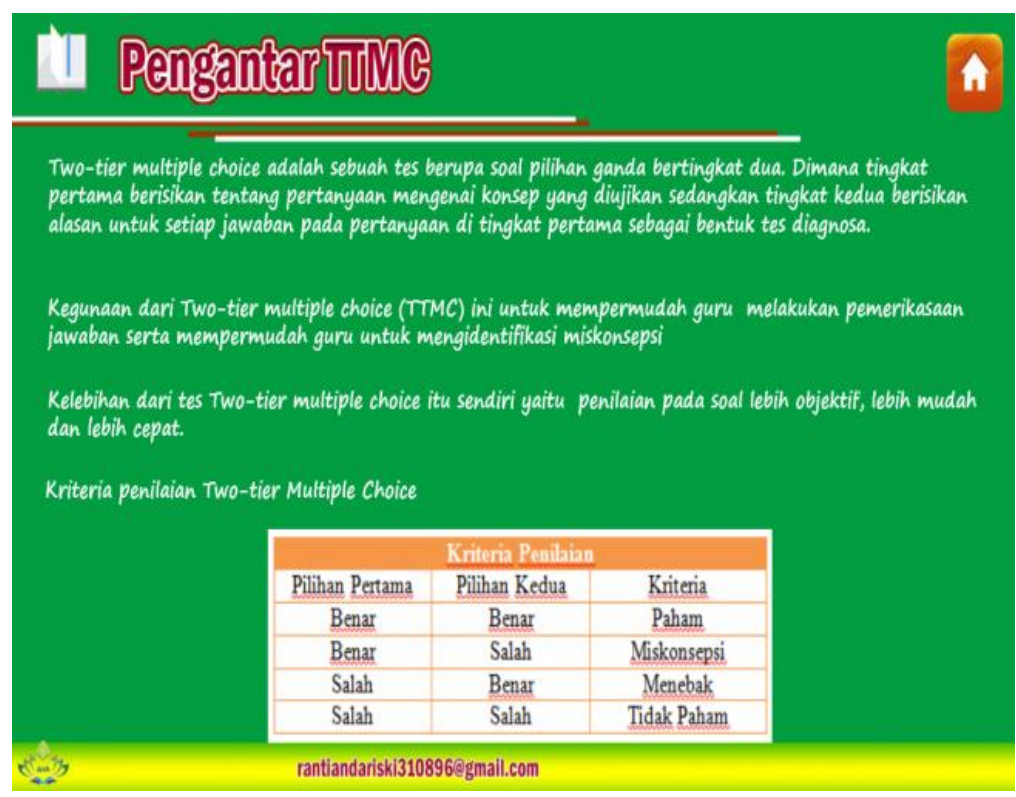

Gambar 2. Tampilan pengantar two-tier multiple choice

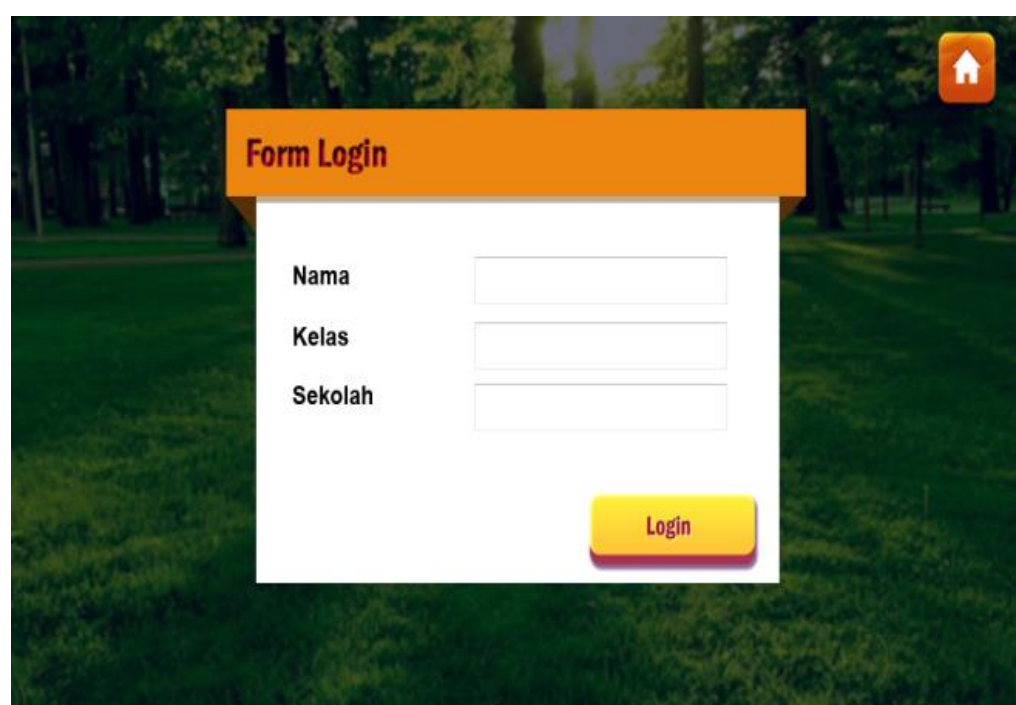

Gambar 3. Tampilan Form login soal two-tier multiple choice

Setelah mendesain produk awal, langkah yang dilakukan yakni melakukan validasi terhadap produk yang akan dikembangkan. Validasi dilaksanakan untuk menguji kelayakan produk yang dikembangkan berdasarkan penilaian dari beberapa validator. (Surahman Ence \& Surjono Herman Dwi, 2017). Validasi dilaksanakan kepada beberapa dosen ahli untuk menilai aplikasi yang telah dibuat oleh peneliti. Peneliti juga meminta penilaian dari 2 orang ahli media, 2 orang ahli evaluasi serta 2 orang ahli bahasa. Hasil validasi tersebut akan dijelaskan pada uraian sebagai berikut. 
Bagian yang perlu dipernilai dari ahli media diantaranya adalah aspek tampilan, aspek pemrograman, dan aspek efektifitas. Hasil yang didapatkan dari validasi ahli media dapat dilihat melalui gafik perbandingan di bawah ini:

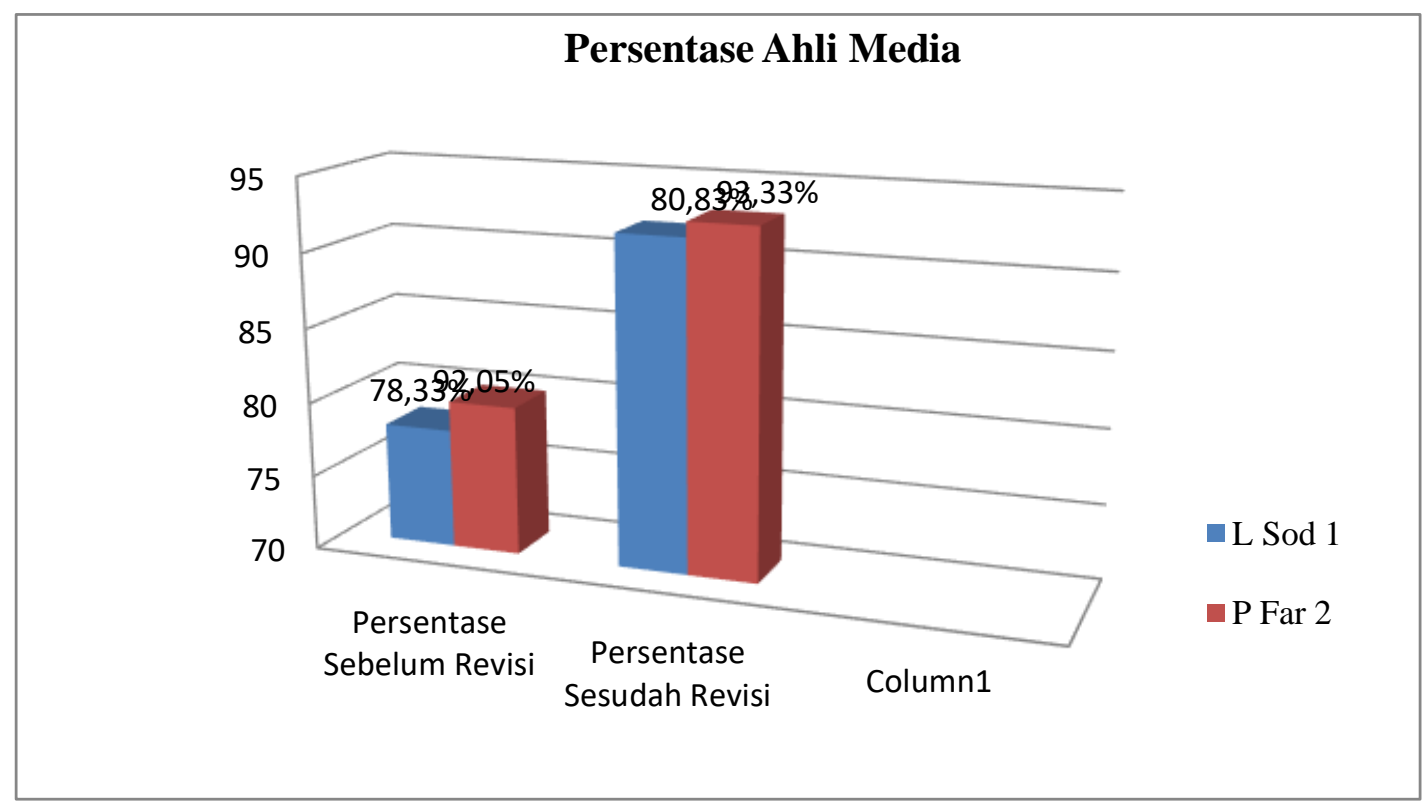

Gambar 4. Hasil Validasi Ahli Media

Berdasarkan gambar di atas nilai pada validasi ahli media pada angket pernyataan positif dan negatif dapat memperoleh persentase rata-rata tiap validator yakni validator 1 ahli media L Sod 1 memeroleh persentase sebesar 92,405\%, kemudian hasil validator 2 ahli media P Far 2 memperoleh persentase sebesar 93,33\% dengan kriteria "sangat layak". Selanjutnya memperoleh persentase dengan rata-rata total dari tiap validator ahli media sebesar 92,69\% dengan kategori sangat layak.

Selanjutnya validasi ahli evaluasi dilakukan sebanyak dua tahap untuk menilai ketepatan konsep evaluasi yang terdapat pada instrumen evaluasi two-tier multiple choice. Ada 3 aspek yang dinilai dari ahli bahasa yakni aspek tampilan,aspek kesesuaian pemograman, dan aspek efektivitas. Hasil yang diperoleh dari validasi ahli evaluasi tahap dua dapat dihat melalui grafik perbandingan sebagai berikut: 


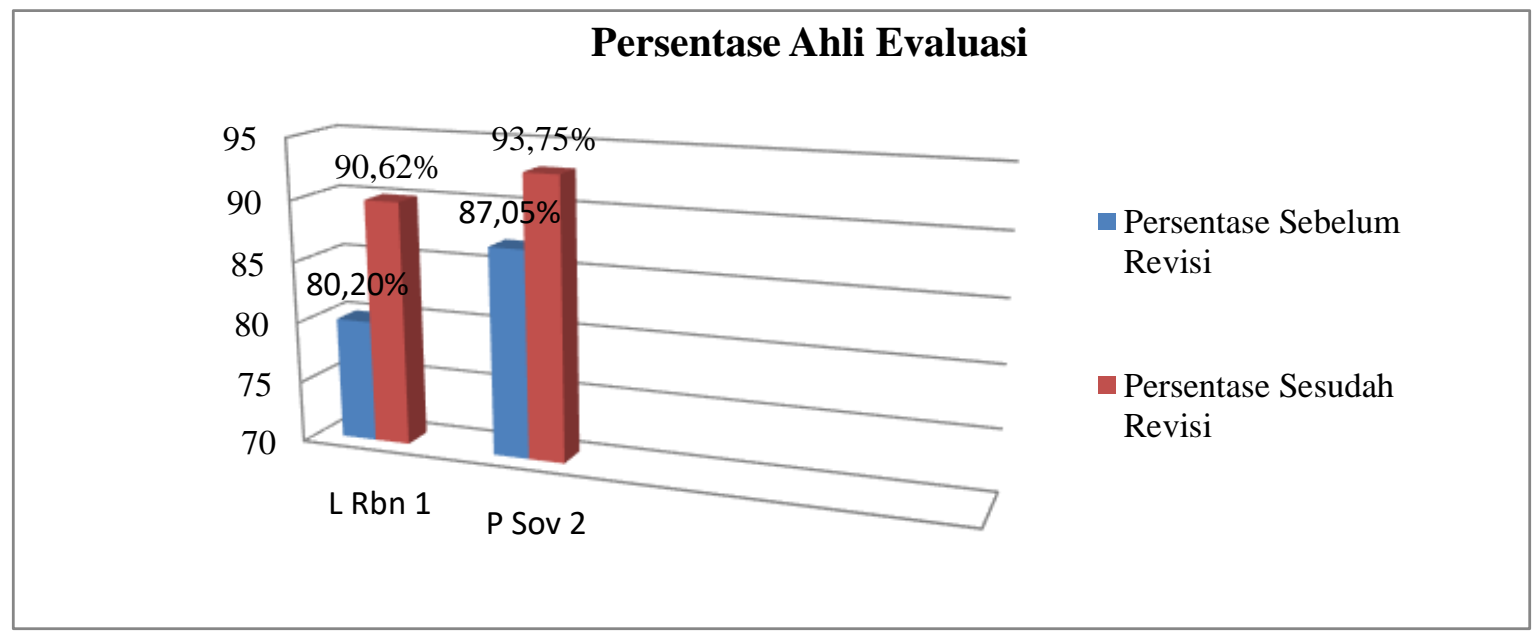

Gambar 5. Hasil Validasi Ahli Evaluasi

Berdasarkan validasi ahli evaluasi diketahui bahwa pesentase validasi sebelum revisi pada validator L Rbn 1 sebesar 80,20\%, sementara pada validator P Sov 2 mendapatkan $87,05 \%$. Selanjutnya hasil validasi sesudah revisi pada validator L Rbn 1 memperoleh peningkatan sebesar 90,62\% sedangkan validator P Sov 2 memberikan penilaian sebesar $93,75 \%$.

Sesudah melakukan validasi ahli evaluasi maka langkah selanjutnya yaitu ahli bahasa. Terdapat 4 aspek yang akan dinilai dari ahli bahasa yakni aspek bahasa, aspek kesesuaian penulisan, aspek dialogis dan interaktif, aspek kesesuaian perkembangan peserta didik, aspek penggunaan istilah simbol, istilah, dan ikon. Adapun hasil yang diperoleh dari validasi ahli bahasa dapat dihat pada Gambar 6 sebagai berikut:

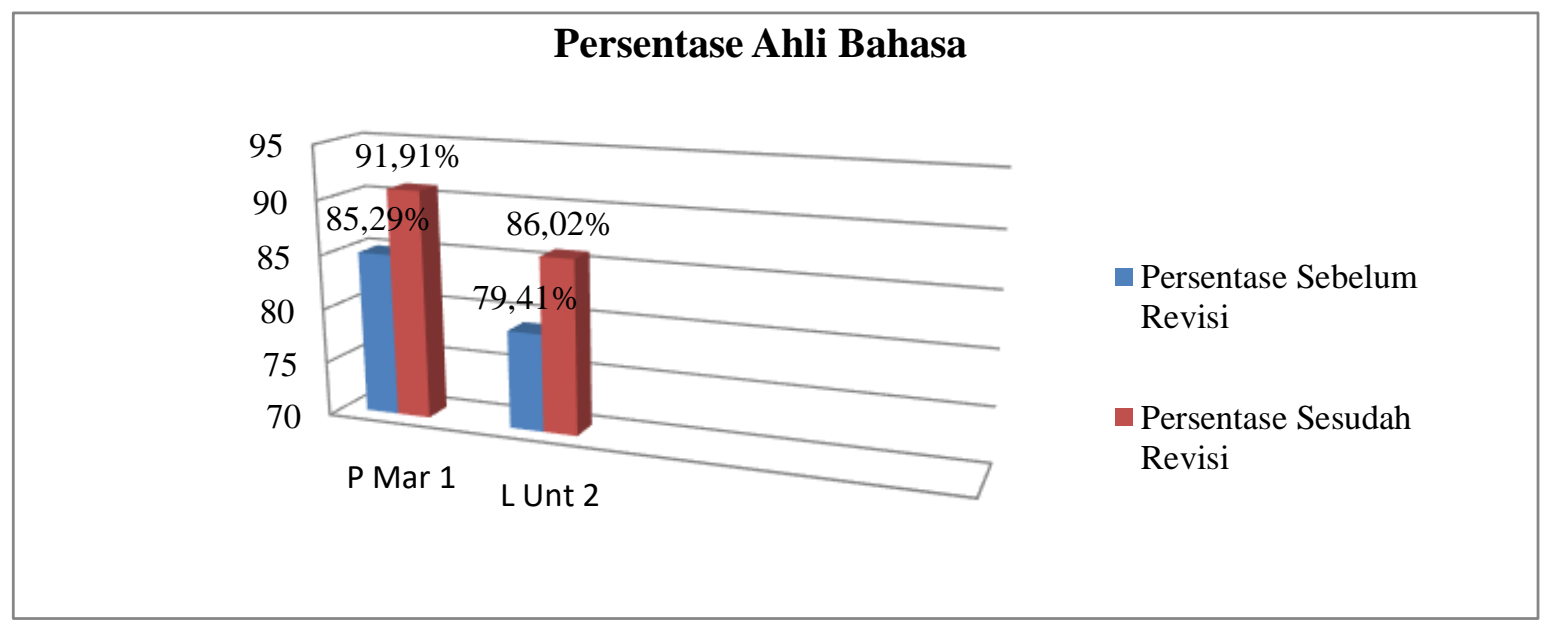

Gambar 6. Hasil Validasi Ahli Bahasa 
Berdasarkan hasil validasi pada ahli bahasa tahap sebelum revisi pada validator $\mathrm{P}$ Mar 1 mendapatkan presentase sebesar 85,29\% sedangkan pada validator L Unt 2 resentase yang diperoleh sebesar 79,41\%. Kemudian pada validasi tahap dua oleh validator P Mar 1 didapatkan presentase sesebesar 91,91\%. Sedangkan pada validator L Unt 2 diperoleh presentase sebesar $86,02 \%$.

Setelah tahap validasi selesai dilakukan pada masing-masing ahli yang telah disebutkan sebelumnya maka diperoleh kesimpulan bahwasaannya pengembangan media mobile learning menggunakan software construct 2 menggunakan personal computer sangat layak digunakan sebagai evaluasi pembelajaan untuk mengukur ketercapaian peserta didik penelitian yang setarapun oleh (Komariah dkk., 2018; Rizkiah dkk., 2018; Saputro dkk., 2018; Septina dkk., 2018). Selanjutnya uji coba produk dilaksanakan pada peserta didik kelas X SMA Al-Azhar 3 Bandar Lampung dan SMA Muhamadiyah 2 Bandar Lampung yang berjumlah 10 peserta didik pada uji coba terbatas dan 30 peserta didik untuk uji coba luas serta melibatkan dua orang responden dari guru biologi. Hasil dari angket responden peserta didik dapat dilihat pada Tabel 3 sebagai berikut.

Tabel 3. Hasil Uji Skala Kecil

\begin{tabular}{cc}
\hline Keterangan & Kriteria \\
\hline Jumlah Skor & 701 \\
Skor Max & 720 \\
Persentase & $97,35 \%$ \\
Kriteria & Sangat Layak \\
\hline
\end{tabular}

Berdasarkan hasil uji dari responden peserta didik pada uji coba terbatas pada tabel diatas bahwa uji coba produk yang melibatkan 10 responden, maka memperoleh seluruh peserta didik dalam uji coba terbatas memberikan penilaian berkitan dengan instrumen evaluasi two-tier multiple choice untuk mengukur literasi sains peserta didik menggunakan personal computer sangat layak untuk dipergunakan sebagai evaluasi pembelajaran. Berdasarkan penilaian dari hasil uji coba terbatas memperoleh jumlah skor sebesar 701 dengan skor maksimal sebesar 720. Data yang didapat tersebut setelah dihitung lalu memperoleh presentase kelayakan sebesar 97,35\%. Maka dapat disimpulkan bahwa produk instrumen evaluasi two-tier multiple choice untuk mengukur literasi sains peserta didik menggunakan personal computer sangat layak digunakan sebagai evaluasi pembelajaran. 
Tabel 4. Hasil Uji Skala Luas I

\begin{tabular}{cc}
\hline Jumlah Skor & 2047 \\
Skor Max & 2140 \\
Persentase & $94,76 \%$ \\
Kriteria & Sangat Layak \\
\hline
\end{tabular}

Tabel 5. Hasil Uji Skala Luas II

\begin{tabular}{cc}
\hline Jumlah Skor & 2089 \\
Skor Max & 2160 \\
Persentase & $96,71 \%$ \\
Kriteria & Sangat Layak \\
\hline
\end{tabular}

Berdasarkan hasil tanggapan peserta didik pada uji coba produk pada Tabel 4 dan Tabel 5 secara lebih luas yang memakai 30 peserta didik SMA Al-Azhar 3 Bandar Lampung dan 30 responden SMA Muhamadiyah 2 Bandar Lampung, diperoleh data bahwa seluruh responden yang ikut memberikan penilaian tentang instrumen evaluasi two-tier multiple choice untuk mengukur literasi sains peserta didik menggunakan personal computer dinyatakan sangat layak begitu pun dengan pengukuran literasi sainsjuga dikatakan layak dalam penelitian yang dilakukan oleh (Mutiara, 2018; Rakhmawati, 2015). Uji coba secara lebih luas memperoleh skor penilaian sebesar 2047 dan 2089, skor maksimal sebesar 2140 dan 2160. Setelah data didapatkan didapatkan maka tingkat kelayakannya memeroleh presentase sebesar 94,76\% dan 96,71\% dapat dikategorikan dengan kategori sangat layak. Maka dapat disimpulkan bahwa instrumen evaluasi two-tier multiple choice untuk mengukur literasi sains peserta didik menggunakan personal computer sangat layak dipergunakan sebagai evaluasi pembelajaran. Selain angket tanggapan peserta didik angket tanggapan mengenai kelayakan instrumen evaluasi two-tier multiple choice yang dikembangkan juga dibagikan kepada dua orang guru biologi. Tabel 6 berikut adalah data respon guru terhadap produk.

Tabel 6. Hasil Respon Guru Terhadap Produk

\begin{tabular}{ccc}
\hline Hasil & P Nan 1 & P Al 2 \\
\hline Persentase rata-rata Validator (\%) & $83,59 \%$ & $91,40 \%$ \\
Kriteria & Sangat Layak & Sangat Layak \\
Persentase rata-rata total & \multicolumn{2}{c}{$87,49 \%$} \\
Kriteria & \multicolumn{2}{c}{ Sangat Layak } \\
\hline
\end{tabular}


Berdasarkan tanggapan yang diberikan oleh kedua responden guru biologi memperoleh presentase rata-rata total sebesar $97,49 \%$ hal ini disimpulkan bahwa instrumen evaluasi two-tier multiple choice untuk mengukur literasi sains menggunakan personal computer layak digunakan sebagai evaluasi pembelajaran di sekolah.

\section{SIMPULAN DAN SARAN}

Penelitian ini dapat disimpulkan bahwa pengembangan instrumen evaluasi Two-tier multiple choice (tersedia di link: http://bit.ly/2uNO6Te) terhadap literasi sains berbantuan personal computer dengan metode pengembangan menurut Borg and Gall sampai langkah ketujuh diantaranya yakni Research and information collecting, planning, Develop prelimiery form of product, Prelimiery field testing, Main product revision, Main field testing dan Operational product revision. Setelah melakukan uji terhadap instrument evaluasi Two-tier multiple choice untuk mengukur literasi sains menggunakan personal computer pada mata pelajaran biologi telah diperoleh penilaian dengan kriteria sangat layak dan sangat menarik.

Penelitian ini menyarankan, hendaknya instrument evaluasi Two-tier multiple choice menggunakan personal computer tersebut dapat dikembangkan secara berkelanjutan pada materi yang berbeda dan hendaknya dikembangkan dengan kolecty data total masuk ke akun pendidik sehingga skor peserta didik dapat secara langsung diketahui oleh pendidik, dan dilakukan secara online dan bisa memanfaatkan moodle atau google classroom.

\section{DAFTAR PUSTAKA}

ADIANSYAH SYAHRUL, D. (2015). Identifikasi Miskonsepsi dan Penyebab Miskonsepsi Siswa dengan Three-tier Diagnostic Test Pada Materi Dinamika Rotasi. Inovasi Pendidikan Fisika, 4(3).

Agustiana, N., Supriadi, N., \& Komarudin, K. (2019). Meningkatkan Kemampuan Penalaran Matematis dengan Penerapan Pendekatan Bridging Analogy Ditinjau dari Self-Efficacy. Inovasi Pembangunan: Jurnal Kelitbangan, 7(1), 61-61.

Aminoto, T. (2014). Penerapan media e-learning berbasis schoology untuk meningkatkan aktivitas dan hasil belajar materi usaha dan energi di kelas xi sma n 10 kota jambi. Sainmatika: Jurnal Sains dan Matematika Universitas Jambi, 8(1).

Amir, M. F. (2015). Proses berpikir kritis siswa sekolah dasar dalam memecahkan masalah berbentuk soal cerita matematika berdasarkan gaya belajar. JURNAL MATH 
EDUCATOR NUSANTARA: Wahana Publikasi Karya Tulis Ilmiah di Bidang Pendidikan Matematika, 1(2).

Anwar, S., \& Fakhruddin, A. (2016). Pelaksanaan Standar Penilaian oleh Guru Pendidikan Agama Islam di Sekolah (Studi Evaluatif terhadap Guru PAI SMP dan SMA di Bandung). Jurnal Pendidikan Agama Islam-Taâ€ $€^{T M}$ lim, 14(2).

Ardiansyah, A. A. I., \& Bahriah, E. S. (2016). Persepsi siswa terhadap penggunaan instrumen three-tier multiple choice berbantuan microsoft office excel. EduChemia (Jurnal Kimia dan Pendidikan), 1(2), 204-214.

Damayanti, D. R., Yamtinah, S., \& Utomo, S. B. (2018). Pengembangan Instrumen Penilaiantwo-Tier Multiple Choice Question Untuk Mengukur Keterampilan Proses Sains Siswa Pada Tema Mata Sebagai Alat Optik. INKUIRI: Jurnal Pendidikan IPA, 7(2), 252-261.

Dawati, F. M., Yamtinah, S., Rahardjo, S. B., Ashadi, A., \& Indriyanti, N. Y. (2017). Uji Validitas Computerized Two-Tier Multiple Choice (CTTMC) Melalui Focus Group Discussion (Fgd) Untuk Mendiagnosis Kesulitan Belajar Siswa. Prosiding SNPS (Seminar Nasional Pendidikan Sains), 260-265.

Dewantari, A. (2015). Pengembangan instrumen asesmen two-tier multiple choice question untuk mengukur keterampilan proses sains siswa pada materi asam basa. UNS (Sebelas Maret University).

Dzulfikar, A., \& Vitantri, C. A. (2017). Miskonsepsi Matematika pada Guru Sekolah Dasar. Suska Journal of Mathematics Education, 3(1), 41-48.

FITRIAWATI, A. (2018). Analisis Kualitas Soal Formatif Semester Genap Pada Mata Pelajaran Sejarah Kelas X Ips Sman 1 Jember Tahun Pelajaran 2017/2018.

Haryati, S. (2014). Pengembangan Intelegensi Majemuk dalam Proses Pembelajaran. Ragam, 14(2).

Hikmah, N., Yamtinah, S., \& Ashadi, A. (2017). Analisis Validitas Isi Instrumen Computerized Two-Tier Multiple Choice (Cttmc) Untuk Mengukur Keterampilan Proses Sains Pada Materi Termokimia. Prosiding SNPS (Seminar Nasional Pendidikan Sains), 40-45.

Indriani, B., \& Suranto, A. W. (2016). Komunikasi Edukatif Dalam Meningkatkan Prestasi Belajar Siswa Mata Pealajaran Kearsipan Kelas Xi Kompetensi Keahlian Administrasi Perkantoran SMK Bhakti Karya 1 Magelang. Jurnal Pendidikan Administrasi Perkantoran-S1, 5(2), 126-135.

Jannah, M. (2013). Pembelajaran Sejarah Pada Kelas Akselerasi Di SMA Pondok Pesantren Modern Islam Assalaam Surakarta. UNS (Sebelas Maret University). 
Karyanti, K., \& Komarudin, K. (2017). Pengaruh model pembelajaran kumon terhadap pemahaman matematis ditinjau dari gaya kognitif peserta didik pada mata pelajaran matematika kelas viii smp negeri satu atap 4 pesawaran. Prosiding Seminar Nasional Matematika dan Pendidikan Matematika, 1, 89-94.

Komariah, S., Suhendri, H., \& Hakim, A. R. (2018). Pengembangan media pembelajaran matematika siswa SMP berbasis Android. JKPM (Jurnal Kajian Pendidikan Matematika), 4(1), 43-52.

Komarudin, K., \& Permana, P. T. (2019). Lkpd Berbasis Scientific Approach Terhadap Kemampuan Pemecahan Masalah Matematis Peserta Didik Sekolah Dasar. TERAMPIL: Jurnal Pendidikan dan Pembelajaran Dasar, 6(1), 79-91.

Komarudin, K., Sujadi, I., \& Kusmayadi, T. A. (2014). Proses Berpikir Kreatif Siswa SMP Dalam Pengajuan Masalah Matematikaditinjau Dari Gaya Kognitif Siswa (Studi Kasus Pada Siswa Kelas Viii-h SMP Negeri 1 Sukoharjo Tahun Pelajaran 2012/2013). Jurnal Pembelajaran Matematika, 2(1).

Lesmono, A. D., Rohmah, R. N., \& Harijanto, A. (2017). Identifikasi miskonsepsi siswa pada pokok bahasan rangkaian arus searah di kelas XII MAN 1 Jember. FKIP $e$ PROCEEDING, 2(1), 7-7.

Maunah, N. (2014). Pengembangan Two-Tier Multiple Choice Diagnostic Test untuk Menganalisis Kesulitan Belajar Siswa Kelas X pada Materi Suhu dan Kalor. Inovasi Pendidikan Fisika, 3(2).

Muhson, A. (2010). Pengembangan media pembelajaran berbasis teknologi informasi. Jurnal Pendidikan Akuntansi Indonesia, 8(2).

Mutiara, E. B. (2018). Pengembangan Lks Biologi Berbasis Guided Inquiry Laboratory Untuk Meningkatkan Literasi Sains Dimensi Proses Pada Mata Pelajaran Biologi. UIN Raden Intan Lampung.

Nofiana, M., \& Karyanto, P. (2013). Pengembangan instrumen evaluasi two-tier multiple choice question untuk mengukur keterampilan berpikir tingkat tinggi pada materi kingdom plantae. Inkuiri, 67291.

Puspitasari, W. D., \& Rodiyana, R. (2019). Bahan Ajar Inquiry Saintifik Untuk Berpikir Kritis Siswa Sekolah Dasar. Jurnal Cakrawala Pendas, 5(2).

Rakhmawati, R. B. (2015). Pengembangan Media Pembelajaran Interaktif Be Fun Chemist Pada Materi Kelarutan dan Hasil Kali Kelarutan Untuk Meningkatkan Literasi Sains dan Hasil Belajar Siswa SMA Kelas XI. UNIVERSITAS NEGERI SEMARANG.

Ratnasari, D., Sukarmin, S., \& Suparmi, S. (2017). Analisis Implementasi Instrumen Twotier Multiple Choice Untuk Mengukur Keterampilan Proses Sains. Jurnal Pendidikan dan Kebudayaan, 2(2), 166-179. 
Rizkiah, A. W., Nasir, N., \& Komarudin, K. (2018). LKPD Discussion Activity Terintegrasi Keislaman dengan Pendekatan Pictorial Riddle pada Materi Pecahan. Desimal: Jurnal Matematika, 1(1), 39-47.

Rodiawati, H., \& Komarudin, K. (2018). Pengembangan e-learning melalui modul interaktif berbasis learning content development system. Jurnal Tatsqif, 16(2), 172185.

Salamah, U. (2018). Penjaminan Mutu Penilaian Pendidikan. EVALUASI: Jurnal Manajemen Pendidikan Islam, 2(1), 274-293.

Sanjaya, W. (2013). Penelitian Pendidikan Jenis, Metode dan Prosedur. Jakarta: Kencana.

Saputro, T. A., Kriswandani, K., \& Ratu, N. (2018). Pengembangan Media Pembelajaran Mengunakan Aplikasi Construct 2 Pada Materi Aljabar Kelas VII. JTAM (Jurnal Teori dan Aplikasi Matematika), 2(1), 1-8.

Septiani, D., \& Sumarni, W. (2014). Efektivitas Model Inkuiri Berbantuan Modul dalam Meningkatkan Pemahaman Konsep dan Keterampilan Generik Sains. Jurnal Inovasi Pendidikan Kimia, 8(2).

Septina, N., Farida, F., \& Komarudin, K. (2018). Pengembangan lembar kerja siswa dengan pendekatan saintifik berbasis kemampuan pemecahan masalah. Jurnal Tatsqif, 16(2), 160-171.

Sulfemi, W. B. (2018). Penggunaan Tames Games Tournament (Tgt) Dengan Media Kartu Dalam Meningkatkan Hasil Belajar. JOURNAL OF KOMODO SCIENCE EDUCATION, 1(01), 1-14.

Surahman Ence, \& Surjono Herman Dwi. (2017). Pengembangan adaptive mobile learning pada mata pelajaran biologi SMA sebagai upaya mendukung proses blended learning. Jurnal Inovasi Teknologi Pendidikan, 4(1), 26-37. https://doi.org/10.21831/jitp.v4i1.9723

THAHIR, A., KOMARUDIN, K., \& HASANAH, U. N. (2019). MURDER Learning Models and Self Efficacy: Impact on Mathematical Reflective Thinking Ability. https://dergipark.org.tr/en/download/article-file/883495

Yulianti, N. (2014). Pengembangan Instrumen Penilaian Psikomotorik pada Pokok Bahasan Suhu dan Kalor di SMP. Jurnal Inovasi Dan Pembelajaran Fisika, 1(2), 152-156. 